\title{
The Law and the Principle of Legality
}

\author{
Sophie Weerts
}

\subsection{INTRODUCTION}

In the European legal tradition, the law embodies the privileged instrument of public action since the emergence of the modern state. Its legitimacy comes from its author-a democratic organ-its content-its presumed rationality - and its formalism-its procedure of adoption and publication. Nevertheless, since the 1990s, social transformations occurred and blurred the concepts of law and state. The foundations of administrative law are particularly involved (Mockle 2007; Caillosse 2015). The law-taken broadly_-sees its field of intervention competing with nonobligatory instruments that bring out the idea of 'soft law'. Such a phenomenon questions what lawyers call the sources of law (Hachez et al. 2010). As for the state, traditionally described by models of liberal state and then social state, fits the model of the 'propulsive state' (Morand 1991) or the 'state - resource manager' (Moor 2005: 63) better. Sovereign powers and social competencies are no longer the main concepts used to analyze the state's actions. A more dynamic concept of public policy has been adopted in which the law takes different forms of normativity. These two trends indicate a general transformation of the law.

\footnotetext{
S. Weerts $(\square)$

IDHEAP, University of Lausanne, Lausanne, Switzerland e-mail: Sophie.Weerts@unil.ch
}

(C) The Author(s) 2019

A. Ladner et al. (eds.), Swiss Public Administration, Governance and Public Management, https://doi.org/10.1007/978-3-319-92381-9_4 
More specifically, in the field of statute law, more and more legal norms are generated by the executive branch. The democratic legitimacy of the law is also called into question when international rules are the basis of public action. Private bodies adopt standards which sometimes are later included in the law (Uhlmann 2013). This evolution highlights a shift in the center of gravity of power that is no longer located in the (representative) democratic body. Normative instruments which are less formalized, such as soft law, are emerging as a new category in the typology of (formal) sources of law. Finally, the infallibility of the law has been questioned with the development of constitutional justice. From the point of view of legal science, some identify the beginnings of a global administrative law (Kingsbury et al. 2005). Others consider that the principle of legality must be revisited (Popelier 2012: 48-54).

In Switzerland, all state activities are based on, and limited by, law (Art. 5 (1), Federal Constitution, abbreviated as Const.). Nevertheless, the definition of the word law is not easy to grasp and does not always fit perfectly with the idea of statutory law. Since the 1990s, Swiss legal scholars have worked on the issue of the law, noting the contextual and structural transformations of state activities (see Moor 1990, 2005; Morand 1991; Müller 2006; Flückiger 2007, 2008).

The following four chapters address many of the issues surrounding the figures of the law. Chapter 5 presents a particular stage in the formation of the law: the pre-parliamentary phase. It evokes the hypothesis of the shift of the center of gravity of the parliamentary to executive power and presents the 'compensation mechanisms' that have been instituted in Swiss law. Chapter 6 deals with the development of international law. Here, the federal administration plays an important role in maintaining the coherence of the Swiss legal system and making it congruent with its international commitments, while respecting the exercise of political (or popular) rights. Chapter 7 examines the phenomenon of soft law in Swiss public law and shows how this mode of public action developed with respect to legislation (the main formal sources of law, called 'hard law'). Finally, the last chapter addresses one of the singularities of Swiss public law: its limited ability to review the constitutionality of laws. Each of these chapters addresses the challenges faced by Swiss law and, in turn, challenges for the public administration which must act within the framework and the limits of the law.

In that context, some basic legal notions are worth presenting. A first one is the understanding of the concept of law (in Swiss law) (Sect. 4.1). 
Indeed, from the strictly legal point of view, it constitutes the first formal source of law within the meaning of Article 1 of the preliminary title of the Civil Code and is understood as written law (statute law). Its corollary is the principle of legality (Sect. 4.2), which is essential in all the activities of the state as stated in Article 5 (1), Const. Both are indispensable for understanding the main features of the legal framework Swiss public administration acts within.

\subsection{The LAW}

The law takes many forms which vary according to legal traditions. In the continental legal tradition, the law is defined as any general and abstract rule resulting from a collective will and endowed with binding force. It corresponds to the idea of legislation. Strictly speaking, it is defined as the acts adopted by the legislative branch (primary legislation), as opposed to the acts (statutory instruments) adopted within the framework of the executive branch and by the administrative authorities (delegated or secondary legislation). This distinction echoes the notions of formal law and material law, formulated by German constitutional theory (Sect. 4.2.1). Both are found in Swiss law, which also makes another crucial difference between 'legal rule' and 'decision' (Sect. 4.2.2). Finally, even if some elements indicate the emergence of a more flexible law (see the chapter by Flückiger), a series of procedural mechanisms also shows the strengthening of the democratic legitimacy of the legal norms (Sect. 4.2.3).

\subsubsection{The Distinction Between Formal Law and Material Law}

The distinction between formal and material law has its origin in German constitutional theory (Popelier 2012: 19 et seq). It allowed the Prince's power to be limited by defining the areas in which he needed to have the support of Parliament. In France, a different conception of the law developed after 1789: the law only rests on the institutions that collectively exercise the legislative function. The government then exercises the executive function and adopts acts to put the law in action. In the French case, the idea of material law was thus not conceivable. In both cases, the explanatory criterion, therefore, lies in the democratic legitimacy of formal law. This is produced by a democratic body, Parliament. This legitimacy justifies its pre-eminence over the acts of government or administrative authorities. 
Formal law, however, competes with other sources. International treaties, European law, or the use of delegated legislation for the benefit of executive authorities are all expressions of a form of law which is no longer the result of the deliberate will of a parliament. They embody the concept of material law. In the field of fundamental rights, the European Convention on Human Rights allows restrictions if they are made in accordance with or prescribed by the law (Art. 8 (2), 9 (2), 10 (2) and 11 (2) ECHR). In its case law, the European Court of Human Rights has nevertheless not made the formal character of the law a condition for a restriction to be valid. It considers that an act corresponds to a law, within the meaning of the European Convention on Human Rights, on four conditions: it constitutes a legal basis for public action, it is accessible to all, the consequences of the law must be foreseeable and the law must, if the act is accessible to individuals, be formulated in precise terms to allow everyone to predict the consequences of their actions (ECHR, Sunday Times vs. The United Kingdom, 1979). Two exceptions, however, are well known. The first is Article $6 \mathrm{ECHR}$, which guarantees the right to a fair trial. In this framework, jurisdiction must be established by legislation to ensure that an individual is not subject to the discretion of the executive. The second is when a national constitution requires that a matter be regulated by legislation (see Popelier: 26-28).

The determination of the form of law is an important element in Swiss public administration, as any public action involves defining an action tool. However, the distinction between formal and substantive law is also present in Swiss law (Auer et al. 2006: 88 et seq). Indeed, several constitutional provisions require the adopting of a law. This varies according to subject, but also according to the degree of restriction of the autonomy of an individual. The general requirement of a law, for example, is laid out in the context of any restriction of fundamental rights. It is listed in Article 36 (1) Const. The statutory requirement is also stated in Article 164 Const. for federal legislation in general. In both cases, the idea of law is a two-way street. Depending on the circumstances, it is either an act adopted by Parliament or an act adopted by an authority empowered to decide. In the fields of taxation-according to the principle of 'no taxation without representation'-(Art.127 (1) Const.), access to justice (Arts. 29a and 30 Const.) and deprivation of liberty (Art. 31 (1) Const.), the requirement of a law is understood within the meaning of formal law. The extent to which individual autonomy, the keystone of the liberal state, is undermined or at risk justifies the public action being taken by a democratically elected 
body. It should be added that Swiss law does provide for an exception to the legal requirement: the general police clause. This clause allows the government to act without any legal basis, and to limit fundamental rights, in the event of preventing or putting an end to a serious and imminent infringement of public order (Aubert and Mahon 2003: 325).

\subsubsection{The Legal Rule as a Criterion for Distinguishing the Legislation}

Between German and French conceptions previously described, Swiss law follows the German tradition. The legislative function can be exercised by the parliament, the people and the executive branch (the Federal Council). The word law - formal law-is reserved for acts adopted by Parliament, possibly with the support of the people. However, the parliament can also adopt ordinances just like the Federal Council. In other words, it is not the author of the legal norms that qualifies the legal act but the content of it.

In Swiss law, when referring to legislation, the determining factor is the legal rules. The notion of a legal rule is defined in Art. 22 (4) of the Federal Act of the Federal Assembly. It refers to the norms of a general and abstract scope addressed to a circle of recipients who are not defined in a precise way (Federal Office of Justice 2007: 229). This could concern all citizens or all motorists. The rule applies to general cases, for example, all instances of speeding, or all taxable income. It is called on to be applied in a repetitive way, that is to say, whenever situations appear which correspond to its abstract hypothesis. It is intended to be sustainable and is presumed stable. These characteristics of generality and stability are key elements in ensuring 'legal certainty' for members of society. Indeed, they allow recipients to predict their actions and the consequences thereof.

However, any act adopted within the framework of public administration is not necessarily a legislative act or a legal rule. If the norm is not general and abstract, then it is called a 'decision'. In this case, the act settles an individual and concrete case. This distinction between legal rule and decision constitutes a fundamental element for the understanding of public administration and Swiss public law in general (see the chapter by Mahon). Indeed, this distinction carries many consequences in terms of the authority's competence, the means of appeal, the mode of communication of the act (official publication of the legislation and notification of the decision) or information contained in the act. In addition, the 
distinction between the two notions is not always easy to identify. Some urban plans are ambivalent acts with a scope that exceeds the individual, without being of general scope. When the public authority is in doubt as to the form of the law it intends to adopt, it must consider whether, to produce its effects, a legal act still needs to be concretized by individual acts; if so, the legal act to be adopted has an indeterminate scope that is characteristic of a legal rule (Federal Office of Justice 2007: 230).

Where the public authorities have to act by legal rules, the form may still vary. At the federal level, it can take the form of a law or ordinance. The Federal Assembly has the power to adopt laws and ordinances (Art. 163 (1) Const.). It also participates in the ratification of international treaties (Art. 14la Const, see the chapter by Weerts and Sofia). Among all these acts, it is the norms that are qualified as 'important' that must take the form of a law. The Constitution states that this concerns the rules relating to the exercise of political rights, the restrictions on constitutional rights, the rights and obligations of persons, the fiscal field, the tasks and services of the Confederation, the obligations of the cantons in the implementation and enforcement of federal law and the organization of the procedure of the federal authorities (Art. 164 (1) Const.). Norms that do not have such a fundamental dimension for individuals or for federal activities can then take the form of an ordinance, which can be passed by the Federal Assembly but also by the Federal Council and the federal administration (departments and offices).

At the federal level, the author of the legislation is either the Parliament or the Federal Council. The most important legislative body is, of course, the Federal Assembly, which is composed of two elected chambers. Laws adopted by the Federal Assembly may still be submitted to a legislative referendum within 100 days of publication in the Federal Gazette (Art. 141 (1) Const.). In this case, the people participate in the adoption of the law. The Federal Assembly also adopts ordinances. For that, it must draw its competence from the Constitution or the law. All acts adopted by the Federal Assembly are not necessarily legal rules. It can adopt decrees as well. These acts have no normative scope. This form of act is used notably for acts which concern the Federal Assembly. The decree is also the legal act adopted by the Federal Assembly in the framework of the ratification process of international law. Depending on the type of treaties ratified, the decree can be submitted to a legislative referendum (see the chapter by Weerts and Sofia). The Federal Council is the second legislative body. It has the power to enact ordinances, which extend the rules contained in 
the primary law (Art. 182 Const.). It may also be empowered to adopt so-called substitution orders. In this case, it must have been given the power to legislate under the Constitution or the law. Finally, the Federal Council can also delegate to the departments of the federal administration the power to enact rules of law (Art. 48 (1) Government and Administration Organization Act).

Once the form and the author of the law have been determined and the content has been set in accordance with legislative procedures, the act produces legal effects as long as it is known by everyone. This requirement presupposes a condition of publication and directly shapes the democratic and liberal state (Hangartner 2008). Under Swiss law, the legislationdomestic law as well as international treaties-is published in the official compendium of federal law (Recueil officiel). At the same time, it is gathered by subject in a systematic collection (Recueil signalétique), which facilitates access to legislation and allows everyone to see the state of the law in force. The publication requirement allows everyone to anticipate the consequences of their activity and to comply with the law. For this purpose, the entry into force does not coincide in principle with the date of publication, except for the constitutional provisions (Art. 195 Const.). In essence, publication must take place at least five days before the entry into force of the law (Art. 7, Publications Act). The decision to enter into force usually belongs to the Federal Council, but it may also have been included in the legislative act itself. For international treaties, it is the treaty itself that contains its own rules of entry into force (Mader 2013: 258-259).

These different elements show that in Swiss public law, the notion of a legislative act encompasses the concepts of formal and material laws. It does not follow the institutional distinction between parliament and government. Thus, the type of legislative acts is not determined according to its author but according to its object. Finally, in all cases, legislative acts must comply with formal requirements.

\subsubsection{Strengthening the Procedural Dimension of the Law}

While it is generally observed that the formal law is losing ground in favor of a substantive conception of the law, Swiss public law has mechanisms and practices that reinforce the procedural dimension of the legislation. From this point of view, these mechanisms and practices reflect an attachment to the law as the first formal source of law, which can also be seen in 
the principle of the immunity clause in the framework of constitutional review (see the chapter by Mahon). These mechanisms and practices illustrate a trend toward an increasing 'proceduralization' of legislation. This can be analyzed as a strengthening of the democratic legitimacy of the law. It accentuates the symbolic value of the law, at the risk of being more focused on a purely formal and non-substantive approach to law. Two elements are a part of such a trend. On the one hand, there is the dissemination of a genuine 'culture of lawmaking' through the federal administration and, on the other hand, the tools of direct democracy.

\subsubsection{The Culture of Lawmaking}

Switzerland has several instruments to ensure the quality of its legislation. All these instruments represent a culture of lawmaking, which can be defined as 'an (applied) science of legislation that seeks to determine the best ways of developing, enacting and applying legal norms' (Chevallier 1998: 15). It addresses the fundamental question of what good law is, a classic theme in the philosophy of law. This concern has become an important aspect of legislative activity when the law is analyzed as one of the resources available to implement state activity in terms of enacted public policies (Knoepfel 2017: 142 et seq.). Several elements can be identified in Swiss public law and public administration as illustrating this approach. Some belong to 'formal lawmaking', others are a part of 'material lawmaking' and both improve the formal and the substantive dimensions of law.

The purpose of drafting formal law is to improve editorial quality and legislative technique. Among the instruments available to Swiss public administration in this area are internal instructions or recommendations of the administration. Another aspect that fits into a culture of drafting formal law is the training of lawyers. Although the drafting of the law is traditionally the prerogative of lawyers, only a few law schools offer courses in drafting law. Such training has therefore been set up in the federal administration and is also open to those without previous legal training. Federal civil servants thus have access to training combining theory and practice, which simultaneously allows the development of a network for sharing experiences. A Swiss Society of Legislation has been created and, under its mandate, three universities offer several courses open to lawyers from cantonal and community administrations. A Legislation Forum has also been created. It is now a network active throughout the executive branch that allows for a fruitful sharing of experiences and which publishes a triennial newsletter. 
The purpose of material lawmaking is to improve the law's ability to act on social reality. In Switzerland, it is implemented through legislative evaluation, since following Art. 170 Const., the Confederation must assess federal measures with regard to their effectiveness (Flückiger: 2007). This generalized what had already been practiced in implementing asylum policies or in efforts to combat inequalities, be it against women or people with disabilities (Mader 2015: 69).

The consultation procedure (Art. 147 Const., see the chapter by GuyEcabert) constitutes a means of acting on the formal as well as the substantive quality of the law. It enables cantons, political parties and interested parties to comment on important legislative acts. It has acquired a certain importance and several qualities are attributed to it (Mader 2013: 255-256). It expands the collection of information about a proposed legislative project, helping to promote greater relevance of the legislative project to social problems, and likely bringing greater legitimacy to it. It is also hoped that the consultation process will foster consensus among political actors, and makes it possible to test the practicability of the proposal with those who will implement it, namely the cantons. In any case, it promotes a process of learning and information to the public when details about the consultation are publicized.

These different elements contribute to strengthening the quality of the law. They are mobilized when the legislative process is initiated by the executive branch, but also - in the case of legislative evaluation-ex post facto. They are grouped into legislative guides (Flückiger and Guy-Ecabert: 2008). These include not only editorial guidelines but also quality standards, methods of codification or consolidation of the law and a periodic review of legislation. However, they remain imperfect. Indeed, they are of little use when the legislative process comes from the parliamentary or popular initiatives. In terms of substantive law, it is not sufficiently integrated by lawyers in administrative or judicial positions. Indeed, the quality of the law is mainly considered with regard to social or economic objectives. It leaves aside social justice dimensions, that is to say its capacity to participate in the realization of constitutional values such as respect for the rule of law, fundamental rights, democracy and federalism, which are part of the law as well and a keystone of liberal democratic states.

\subsubsection{Instruments of Direct Democracy}

The extension of political rights (or 'popular rights') is the second element reinforcing the procedural dimension of the law. They allow citizens to par- 
ticipate in decision-making through voting. In Switzerland, popular rights are provided at federal, cantonal and communal levels. At the federal level, they have been progressively expanded. They were first instituted with the constitutional referendum (since 1848), then the optional legislative referendum (1874), the constitutional initiative (1891) and finally the referendum on international treaties (implemented progressively in 1921, 1977 and 2003; see Chap. 6, Weerts and Sofia). Their use strengthens the democratic legitimacy of legislative acts, which were historically derived, at the federal level, from their adoption by democratically elected institutions.

At the federal level, the participation of the people in the legislative process varies according to the form of the legal act (Art. 138-142, 193, 194 Const.), of which there are three categories: the constitution, the law and the decrees ratifying the texts of international law. The procedure for popular participation varies according to the form of the legislative act. In some cases, the people must participate in the legislative process, in a broad sense, when there is a mandatory referendum. In other cases, people can intervene in the legislative process (optional referendum).

The procedural requirements are laid out in the Federal Constitution and in the Federal Act on Political Rights (Art. 68 to 76, Political Rights Act). The number of signatures required is set by the Federal Constitution. The referendum is obligatory in the case of revisions of the Constitution and accession to international organizations. These call for a dual majority, of both the voters and the cantons. In this case, there is no requirement to collect signatures (Auer et al. 2013: 810-819). At the constitutional level, people can also propose changes by using the 'popular initiative' (Art. 138 and 139 Const.). If they collect the signatures of 100,000 eligible voters, a vote has to be organized within 18 months after the official publication of their initiative. The optional referendum can be triggered with regard to federal laws but also relative to the ratification of international treaties (Art. 141 (1) Const.; Art. 59 to 67 Political Rights Act). A vote will be held if 50,000 eligible voters or eight cantons request it within 100 days of the official publication of a federal law (Art. 141 (1) lit. a Const.).

Since 1848, 617 federal votes (referenda and initiatives) have been held. ${ }^{1}$ Since 1970 , their frequency has increased. They peaked between

\footnotetext{
${ }^{1}$ Federal Statistical Office, https://www.bfs.admin.ch/bfs/fr/home/statistiques/politique/votations.html\#1384097411 (consulted on April 5, 2018).
} 
1990 and 1999, achieving a number of 100 votes. ${ }^{2}$ In such a trend, one instrument has been very successful: the popular initiative. Thirty-nine of these latter have already been addressed between 2010 and $2018^{3}$ (Federal Chancellery: 2018). This trend indicates an increasing participation of citizens in setting the political agenda, even if such a participation is mainly activated by political parties.

\subsection{The Principle of Legality}

The other figure of the law is embodied in the principle of legality. This principle is enshrined in Article 5 (1) of the Federal Constitution and reads: 'all activities of the state are based on and limited by law'. The other paragraphs of this Article require the Confederation and the cantons to act or respect the principles of public interest and of proportionality (2), the principle of good faith (3) and international law (4). All these elements are described as constituting the rule of law.

Before its 1999 revision, this principle of legality was not explicitly stated in the constitutional text. However, it already guided the action of the state, having the form of an 'unwritten constitutional principle' unanimously recognized by doctrine and jurisprudence (Federal Council 1997: 133), and having a binding value recognized by all. This is not the only unwritten constitutional principle: not all laws, or all legal principles, are contained in written acts.

The function of the principle of legality is to limit and regulate the activities of the state. For individuals, the principle of legality is an important element in terms of legal certainty and equal treatment. The legal doctrine (Aubert and Mahon 2003: 41) considers that all collectivities and public institutions are intended. It is thus aimed at the Confederation, the cantons, the communes, but also all the individuals who assume, by delegation, tasks of the state. In addition, the principle applies to all activities of the state, meaning not only activities that limit the rights of individuals but also those that provide benefits to individuals or activities related to state organization (Tanquerel 2011: 152).

\footnotetext{
${ }^{2}$ Federal Statistical Office, 'Évolution de la participation aux votations populaires fédérales'. https://www.bfs.admin.ch/bfs/fr/home/statistiques/politique/votations/participation. assetdetail.3602769.html. Bern: Swiss Confederation (consulted on April 5, 2018).

${ }^{3}$ Federal Chancellery, 'Initiatives populaires ayant fait l'objet d'une votation'. https:// www.bk.admin.ch/ch/f/pore/vi/vis_2_2_5_7.html\#. Bern: Swiss Confederation (consulted on April 5, 2018).
} 
In Swiss law, the principle of legality contains two aspects (Federal Council 1997: 133). The first aspect is called the 'primacy of the law' (Sect. 4.3.1); the second is the 'reserve of the law' (Sect. 4.3.2). These two aspects mean that the principle of legality embodies the formal dimension of the rule of law (Epiney 2015: 93).

\subsubsection{The 'Primacy of the Law' and Its Corollary, the Hievarchy of Norms}

The 'primacy of the law' aspect means that the public administration must respect the law. This requirement applies to all laws, formal and material and to all activities. Such an affirmation must be understood in the light of the hierarchy of norms.

Simply put, the hierarchy of norms means that lower-level acts are subordinate to superior acts, thus putting the legal system in order. This subordination implies that every act of public administration respects the higher standards. The hierarchy is first of all between the legal orders (international law/domestic law) and then within each legal order. Thus, a 'decision' must respect a 'material law' and this one must in turn respect a 'formal law'. It should be noted, however, that legal norms have become more complex and call into question the idea of a well-ordered hierarchy. Without going into this debate, it can be noted that the ordering of the legal system is built on the basis of a combination of legal rules enshrined in the Federal Constitution and rules of interpretation (Haller 2016: 20-26; Mahon 2014: 65-68).

A series of legal acts can be identified. First, there is the Constitution itself, which is adopted on the basis of a particular procedure (Art. 192 to 195 Const.). Then the Constitution designates several legal acts which have a federal rank such as statutes (Art. 164 Const.), ordinances and orders. Some of the ordinances are adopted by the Federal Assembly (Art. 163 Const.) and others are adopted by the Federal Council (Art. 182 Const.). Laws and ordinances constitute the essence of domestic law. In a federal system, the legal system also has several subsystems. There is cantonal law (Article 49 Const.). Each canton has a constitution, which in turn sets its list of legislative acts. Thus, within each canton, there are laws - formal law-and decrees or ordinances-material law. Municipal law is still a third tier of the Swiss legal system (Art. 50 Const.). All these federal, cantonal and communal rules are adopted unilaterally. However, Swiss law also has legislative acts that are adopted in a contractual sense. 
Among these rules, there are 'intercantonal concordats' (see Chaps. 1 and 2 by Ladner). This form of acts does not belong to cantonal law. It is also not included in federal law, although the Confederation can also-within the limits of its powers-participate in these concordats (Art. 48 para. 2 Const.). Swiss law also incorporates rules of international law. Some are negotiated and adopted between states and take the form of bilateral or multilateral conventions and treaties. As for European regulations and directives, they are generally taken up through the practice of autonomous adaptation. Switzerland creates standards equivalent to European law, these European-inspired standards thus taking the legislative forms of classical federal law.

The Swiss Federal Constitution does not provide for a general rule of organization or articulation between all these legal norms. Several elements, however, make it possible to reconstruct the matrix of the Swiss legal system.

First, from the point of view of international law, every state party to a treaty is bound by the principle of pacta sunt servanda ('agreements must be kept'). This customary principle is declined in Art. 26, 27 and 46 (1) of the Vienna Convention on the Law of Treaties. It requires the state which is a party to a treaty to respect its international obligations, regardless of its domestic law. In other words, international law imposes the primacy of international law on the signatory state that has ratified rules of international law.

The Constitution provides also several indications of its commitment to the respect of international law. Articles 139 (3), 193 (4), and 194 (2) Const. indicate that popular initiatives must respect the imperative rules of international law ( jus cogens or 'compelling law'). In addition, Article 5 (4) indicates that the Confederation and the cantons respect international law. Nevertheless, this does not follow the wording of Article 46 (1) Const. according to which federal law takes precedence over cantonal law. This choice of wording is analyzed as the result of a political compromise (Mahon 2014: 48-49). The case law of the Federal Court (the Schubert case), which had not been consistent on the principle of primacy of federal law over domestic law, explains such a nuance. Since then, however, the Federal Tribunal has been consistent in favor of the primacy of international law. The principle of the primacy of federal law flows from the very nature of the international rule, hierarchically superior to any internal rule (Federal Supreme Court: ATF 131 V 66). In 2012, it indicated that international law takes precedence over domestic law (Federal Supreme Court: 
ATF 139 I 16), without addressing a rigid clause of precedent rule (Keller and Balazs-Hegedüs 2016: 717).

However, the question of the primacy of international law over domestic law is a subject of intense political discussions. By virtue of their sovereignty, states may decide to denounce their commitments, but they will take the risk of threatening their international credibility with their partners (Keller and Balazs-Hegedüs 2016: 719). If they violate their international obligations, they then engage their international responsibility (Kolb 2016: 572-573).

Within the Swiss legal system, it is necessary to distinguish between the federal level and the cantonal level. Federal law-Constitution, federal laws and ordinances-prevails over cantonal law (Art. 46 para.1 Const.). Within each level, there are also hierarchical rules according to the type of standards. Thus, the constitution prevails over the law. The supremacy of the Constitution stems from the fact that the other rules of domestic law have their source in the Federal Constitution, which is pre-eminent over other sources of law. Laws are formulated on the basis of the Constitution and they are implemented by the ordinance (Art. 182 Const.).

Courts and legal scholars have developed interpretative methods. The first of them, deduced from the above-mentioned constitutional rules, derives from the maxim lex superior derogat legi inferiori ('a law higher in the hierarchy displaces a lower law'). The two others apply in the context of conflict between standards of the same level. The first provides that the special rule derogates from the general rule and the second implies that the subsequent rule derogates from the previous rule. The method of interpretation in conformity with the Constitution is also used by the judge to develop an interpretation of the legal norm in line with the values of the constitution.

All of these provisions and rules of interpretation help lawyers to maintain, as far as possible, coherence between the legal norms within the Swiss legal order.

\subsubsection{The Requirement of a Legal Basis}

The second aspect of the principle of legality is generally named as the 'reserve of the law'. This is the principle of requirement of the legal basis and means that, except in cases of force majeure, any state activities must be based on a legal rule (Schindler 2014: 118). This aspect of the principle 
of legality allows individuals to foresee the consequences of their actions but also guarantees they will be treated equally.

The requirement of a legal basis can take the form of a formal law but also of a material law. However, it is in this dimension that the principle of legality presents its most flexible aspect, thus being able to fit the contours and specificities of public administration.

As noted above, the choice of the legal basis will depend on the type of intervention. In some areas, such as criminal law or questions of taxation, formal law is a condition for the state's action. In other areas, material law is sufficient. In the event of restricting personal freedom, the greater the degree of infringement, the higher the legislative quality of the rule.

If the legal basis is material law, its legal quality will be assessed according to its accuracy. This element makes it possible to assess the degree of predictability of the law for the citizen. However, practice shows that the degree of accuracy is a criterion that can be easily achieved. This flexibility is accepted on the grounds that, on the one hand, the legislator cannot foresee everything, and, on the other hand, it is also up to the judge to give a more precise content to the legal basis. It is the elements of the hypothesis of application that will then make it possible to determine the degree of precision of the legal rule. In general, the more numerous the persons targeted by the norm, the greater the infringements on personal freedom, the more likely the situations concerned, the more important the accuracy of the norm must be (Tanquerel 2011: 158).

\subsection{Conclusion}

The aim of this chapter was to introduce two basic legal notions of Swiss law, both crucial for public administration: the law and the principle of legality. Starting with the concept of law, it showed that the law does not only consist in written laws adopted by Parliament (formal law), but includes norms adopted by the executive branch and public authorities (material law). The two aspects ('primacy of law' and 'requirement of legal basis') of the principle of legality each refer to the law as well. Their description made it clear that formal and material laws are part of the Swiss law. In the Federal Council's message on the total revision of the Constitution, the term law was defined as referring to the Constitution, the law and ordinances (Federal Council 1997: 134).

Nevertheless, the law implicitly referred to rules of conflict between norms established by legal doctrine and jurisprudence (Federal Council 
1997: 134). In other words, law also referred to something which was not explicitly included in legislation. On this point, another example shows that Swiss law is not limited to statutory law. In the framework of revising the Federal Constitution in 1999, described as a 'fundamental reform' and an 'update' of constitutional law (Federal Council 1997: 20 and 9), the idea of a material constitution was evoked. Adopting this new text was justified by the fact that the 1874 Constitution-a formal law-did not encompass all of Swiss constitutional law. The idea of material Constitution was used to designate all the rules and principles, which form constitutional law (Aubert 1993: 101-103). It referred to constitutional systems without a written constitution, such as those found in the United Kingdom or New Zealand. It then included the practice of the Federal Assembly and the Federal Council, the case law of the Federal Court, as well as many norms of international law, which Switzerland has undertaken to respect (Federal Council 1997: 17). The revision of the Constitution did not codify this entire material constitution, for 'the text of the Constitution never fully restores substantive constitutional law' (Federal Council 1997: 19). This conception of the Constitution, therefore, indicates that Switzerland has a 'living constitution' that has evolved over time, but especially with respect to the scope given to its values. Here, the judge plays a major role. Respect for fundamental rights, democracy and the separation of powers and federalism represent these Swiss constitutional values and contribute to shaping the activities and limits of the state, and that includes Swiss public administration.

Yet, as we have noted, the formalistic dimension of the law develops as well. Several elements show such a trend. This was the case with the requirement of a certain legal quality of laws set in guidelines for specific methods of codification or with the federal consultation procedure. It was also the case with the enlargement of the popular participation in ratification procedure of some international treaties, which has added an extra formal condition to the validity of the ratification.

\section{REFERENCES}

Aubert, J.-F. (1993). Traité de droit constitutionnel suisse. Neuchâtel: Ides et Calendes.

Aubert, J.-F., \& Mahon, P. (2003). Petit traité de la Constitution fédérale de la Confédération suisse du 18 avril 1999. Zurich/Basel/Geneva: Schulthess. 
Auer, A., Malinverni, G., \& Hottelier, M. (2006). Droit constitutionnel, vol. I. Berne: Staempfli.

Auer, A., Malinverni, G., \& Hottelier, M. (2013). Droit constitutionnel suisse (Vol. I, 2nd ed.). Bern: Stämpfli.

Caillosse, J. (2015). L'État du droit administratif. Paris: LGDJ Lextenso éditions.

Chevallier, J. (1998). Vers un droit post-moderne ? Les transformations de la régulation juridique, Revue du droit public, 3, 659-714.

Epiney, A. (2015). Art. 5. In B. Waldmann, E. M. Belser, \& A. Epiney (Eds.), Bundesverfassung (pp. 85-133). Basel: Helbing Lichtenhahn.

Federal Council. (1997). Message du Conseil fédéral du 20 novembre 1996 relatif à une nouvelle constitution fédérale. Fenille fédérale I, 1-653.

Federal Office of Justice. (2007). Guide de législation, Guide pour l'élaboration de la législation fédérale. Bern: Swiss Confederation.

Flückiger, A. (2007). L'évaluation législative ou comment mesurer l'efficacité des lois. Revue européenne des sciences sociales. European Journal of Social Sciences, XLV-138, 83-101.

Flückiger, A. (2008). Qu'est-ce que "mieux légiférer"?: enjeux et instrumentalisation de la notion de qualité législative. In A. Flückiger \& C. Guy-Ecabert (Eds.), Guider les parlements et les gouvernements pour mieux légiférer: le rôle des guides de légistique (pp. 11-32). Geneva: Schulthess.

Flückiger, A., \& Guy-Ecabert, C. (2008). Guider les parlements et les gouvernements pour mieux légiférer: le rôle des guides de légistique. Geneva: Schulthess.

Hachez, I., Cartuyvels, Y., Dumont, H., Gérard, P., Ost, F., \& van de Kerchove, M. (2010). Les sources du droit revisitées (Vol. 4). Limal: Anthemis.

Haller, W. (2016). The Swiss Constitution in a Comparative Context. Zurich/St Gall: Dike.

Hangartner, Y. (2008). Kommentar zu Art. 5 BV. In B. Erhenzeller, B. Schindler, R. J. Schweizer, \& K. A. Vallender (Eds.), Die Schweizerische Bundesverfassung. St Galler Kommentar (pp. 99-125). Zürich/St. Gallen: Dike/Schulthess.

Keller, H., \& Balazs-Hegedüs, N. (2016). Anspruch und Realität der «Selbstbestimmungsinitiative». Aktuelle Juristische Praxis, 6, 712-724.

Kingsbury, B., Krisch, N., \& Stewart, R. B. (2005). The emergence of global administrative law. Law \& Contemporary Problems, 68(3/4), 15-61.

Knoepfel, P. (2017). Les ressources d'action publique. Vers une nouvelle lecture du pouvoir. Zurich/Geneva: Seismo.

Kolb, R. (2016). L'initiative de l'UDC sur l'autodétermination ( "juges étrangers »). Swiss Review of International and European Law, 26, 567-580.

Mader, L. (2013). Législation. In A. Ladner, J.-L. Chappelet, Y. Emery, P. Knoepfel, L. Mader, N. Soguel, \& F. Varone (Eds.), Manuel d'administration publique Suisse (pp. 245-265). Lausanne: Presses polytechniques et universitaires romandes. 
Mader, L. (2015). Les rôles des clauses d'évaluations dans le processus législatif fédéral. In K. Horber-Papazian (Ed.), Regards croisés sur l'évaluation (pp. 67-78). Lausanne: Presses polytechniques et universitaires romandes.

Mahon, P. (2014). Droit Constitutionnel. Institutions, juridiction constitutionnelle et procédure (Vol. 1). Basel: Helbing Lichtenhahn.

Mockle, D. (2007). La gouvernance, le droit et l'État. Bruxelles: Bruylant.

Moor, P. (1990). Introduction à la théorie de la légalité. In C.-A. Morand (Ed.), Les figures de la légalité (pp. 11-28). Paris: Publisud.

Moor, P. (2005). Pour une théorie micropolitique du droit. Paris: Presses universitaires de France.

Morand, C.-A. (1991). L'Etat propulsif: contribution à l'étude des instruments d'action de l'Etat. Paris: Publisud.

Müller, G. (2006). Elemente einer Rechstsetzungslehre. Zurich/Basel/Geneva: Schulthess.

Popelier, P. (2012). La loi aujourd'hui (le principe de légalité). In I. Hachez et al. (Eds.), Les sources du droit revisitées (Vol. 2, pp. 17-54). Limal: Anthémis.

Schindler, B. (2014). Art.5 abs 1-2. In B. Erhenzeller, B. Schindler, R. J. Schweizer, \& K. A. Vallender (Eds.), Die Schweizerische Bundesperfassung. St Galler Kommentar (pp. 103-142). Zürich/St. Gallen: Dike/Schulthess.

Tanquerel, T. (2011). Manuel de droit administrative. Geneva/Zurich/Basel: Schulthess.

Uhlmann, F. (2013). Die Normen können bei...bezorgen werden - gedanken zur Publikation und Verbindlichkeit privater Normen. LeGes, 1, 89-104.

Open Access This chapter is licensed under the terms of the Creative Commons Attribution 4.0 International License (http://creativecommons.org/licenses/ by $/ 4.0 /$ ), which permits use, sharing, adaptation, distribution and reproduction in any medium or format, as long as you give appropriate credit to the original author(s) and the source, provide a link to the Creative Commons license and indicate if changes were made.

The images or other third party material in this chapter are included in the chapter's Creative Commons license, unless indicated otherwise in a credit line to the material. If material is not included in the chapter's Creative Commons license and your intended use is not permitted by statutory regulation or exceeds the permitted use, you will need to obtain permission directly from the copyright holder.

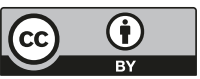

